\title{
Brazilian Perspectives: Society, Stratification and Income Distribution
}

\author{
Ivonaldo Leite \\ Center for Applied Science and Education Federal \\ University of Paraíba, Brazil \\ Email: ivonaldo.leite [AT] gmail.com
}

\begin{abstract}
This paper aims to present a general evaluation on the inequality, income distribution and social mobility in Brazil between 2002 and 2014, under the governments of the Workers' Party. In this way, from the methodological point view, it is based on both a review of the literature about that subject and an investigation of the primary sources of the Brazilian social policies. Among the results found out, it can be highlighting the following sample: 1) historically, Brazilian society has been marked by inequality in several ways, and this is probably a consequence of his colonial legacy; 2) In the period between 2002 and 2014, Brazilian social inequality declined; 3) the decline of inequality can be explained by income growth, higher schooling levels and labor formalization, but the targeted social program, Bolsa Família, also contributed to income convergence; 4) Brazil slashed poverty from 25 percent of the population in 2004 to 8.5 percent in 2014, and extreme poverty declined from 12 to 4 percent over the same period. Conclusively, it's affirmed, for example, that the reduction of inequality in Brazil was the result of firm political decisions, as well as of the quality in management and implementation of the public policies by the technical teams.
\end{abstract}

Keywords: Stratification, income, inequality, social mobility, Brazil

\section{INTRODUCTION}

Social stratification can be understood as the arrangement in which the different groups of society are organized in a higher or lower status and enjoy privileges and suffer disabilities according to their status. In other words, it's the division of society in permanent groups or categories linked with each other by the relationships of superiority and subordination (Kinloch, 1987).

It's well known that, in a society, different individuals perform different roles, whatever may be the cause of such differentiation. This leads us to inquire about the bases of stratification. They are biological and sociocultural, although often the sociocultural origin of social stratification is not adequately addressed. The biological bases depend upon biological distinctions like sex, age, race and birth. On the other hand, the sociocultural bases refer, for instance, economic position, political power and religious strength.

The economic position has a strong influence on the determination of the other levels of the social stratification. Since ancient times, economic positions have originated divisions of classes. As stated by Veblen (2007), the higher-class is a leisure class, while for Pareto (1968) it's elite. Alongside the economic status, and even as a consequence of it, one finds a stratification based upon distinctions of political power. Examples of this basis of stratification may be seen in monarchies, dictatorships and also in democracies. However, in open societies, stratification is not static. It's dynamic, and this dynamic it's called social mobility.

We can understand by mobility any transition of an individual from one social position to another (Goldthorpe, 2005). In this sense, it is possible to identify two types of mobility: horizontal or the transition of an individual from one group to another which oppies the same level; and vertical or the movement of an individual from one social stratum to another, according to its economic, political and occupational forms. Often vertical social mobility is not free; the transition from one stratum to another has occurred under resistance.

Some channels of social mobility are, for instance, the school and professions. Overall, the channels of social mobility select and distribute the individuals within different social strata or positions. Some of them have the functions of testing for the general qualities of the persons, such as intelligence and social characteristics (Goldthorpe, 2005). There are others that test for the specific qualities of individuals necessary for successful full performance of various functions in the society.

Mobility generates positive effects on social system. As examples of such effects, it is possible to cite the following facts: human behavior becomes more plastic and versatile, increase of mobility tends to reduce narrow mindedness, mobility facilitates invention and discoveries.

\section{INEQUALITIES IN BRAZIL}

Historically, Brazilian society has been described as a society marked by inequality in several ways (Cogneau and Gingnoux, 2005). Probably, the colonial legacy weighs heavy from this point of view, as Brazil was the region's main 
slave country. Correlatively, the Brazilian economy and society display an extremely high degree of dualism, visible both in the education system (private/state) and on the labor market (official/unofficial).

Moreover, the imperfections of the credit market have negatively influenced Brazil, especially during the military dictatorship, in the period between 1964 and 1985. There was favoritism for specific economic groups that supported the rulers of this time. This alone might already be an inequality-augmenting fact.

In some phases of its history, Brazil has grown so fast, but at the same time it has also presented one of the world's highest Gini coefficients, as the table 1 demonstrates.

Table 1: Output Growth and Income Distribution in Brazil, 1960-2000

\begin{tabular}{|c|c|c|c|}
\hline \multicolumn{4}{|c|}{ Table 1: Output Growth and Income Distribution in Brazil, 1960-2000 } \\
\hline Decade & Percent growth & Year & Gini index \\
\hline $1960-1970$ & $82.0 \%$ & 1970 & .568 \\
\hline $1970-1980$ & $129 . \%$ & 1980 & .59 \\
\hline $1980-1990$ & $16.9 \%$ & 1990 & .615 \\
\hline $1990-2000$ & $27.8 \%$ & 2000 & .611 \\
\hline
\end{tabular}

Source: Smith (2008)

Basically, the associated Gini indices show a strong rise in inequality between 1960 and 1970, a decade of positive net growth, from .50 to .568 , and a further rise in inequality to .59 between 1970 and 1980, a decade of more consistent, though less dramatic growth. In the 1980s and 1990s, on a decade-to-decade basis, in spite of the relative stagnation of these two decades, inequality either rose or was stable. It did not decline.

The differentiation of human capital levels is one of the factors that contribute to income inequality in Brazil. People differ in all kind of educational aspects that are relevant to the income they achieve. Such differences in human capital result in different returns on the labor market. The more unequal the distribution of human capital and the higher the return to education, i.e. a skill premium, the more unequal will also the income be distributed.

The historical unequal distribution of human capital in Brazil is a widely recognized fact. The data available in 2010 showed a consistent perspective of this problem. In this sense, the numbers in Table 2 present the percentages of the population aged 25 or older who have attained and completed primary, secondary and tertiary level of education.

Table 2: Education levels in Brazil 2010

\begin{tabular}{|c|c|}
\hline Level of schooling & \% attained (\% completed) \\
\hline Primary schooling & $39(26.2$ completed $)$ \\
\hline Secondary schooling & $40.3(25.1$ completed $)$ \\
\hline Tertiary schooling & $7.3(5.2$ completed $)$ \\
\hline
\end{tabular}

Source: Barro and Lee (2010)

The unequal distribution of human capital in Brazil is strongly connected to social origin of people. Consequently, equality of opportunity is not generated, since it exists when the distribution of expected earnings is independent of social origins, and then methodologically the extent of equality of opportunity is measured by an indicator of the inequality of income expectations obtained by individuals of different origins (Van de Gaer, 1993). These conditional income expectations can be obtained from the distribution of average earnings estimated by categories of origin. ${ }^{1}$

But income inequality can also be caused by other factors. For instance, "there can be geographical differences, gender or race-discrimination, technology changes or international trade increases that favor the already skilled and highearning share of the population or the role the government plays when it comes to inequality, mainly through its redistribution policies it will implement" (Keller, 2012, p.13).

In such regard, it can be mentioned the income differences among the Brazilian regions. The Instituto Brasileiro de Geografia e Estatística (Brazilian Institute of Geography and Statistics), hereafter IBGE, categorizes the country into five big regions, and according to this categorization it's possible to find out variations of the income distributions from state to state. Historically, for example, the Gini coefficient of the most unequal state has been 18 percent higher than the national Gini ratio, whereas the Gini of the least unequal state has been almost 20 percent lower than the national ratio (IBGE, 2014).

However, in last times, some studies have pointed out to the decline of the Brazilian social inequality (Góes and Karkowichz, 2017; Cogneau and Gignoux, 2008; Smith, 2008; Medeiros, 2016). Overall, these studies emphasize that such reduction was intensified especially in the Lula da Silva and Dilma Rousseff administrations, corresponding to the period from 2003 to 2016.

\section{CHANGE IN INEQUALITY IN BRAZIL: PERSPECTIVES AND INTERPRETATIONS}

First of all, largely the studies on the improvement of income distribution in Brazil emphasize that the Brazilian inequality comes with a high degree of intergenerational transmission of education, occupational status, or income. So, one of the main questions that they posed concerns the contribution of education to the reduction of economic inequality. It's affirmed that "education is one prominent channel through which parental resources, and in particular parental education, influence the labor market position and the living standard of individuals" (Cogneau and Gignoux, 2008, p. 48). 
This perspective ties in with a contemporary political issue in Brazil, since the country set up extensive meansbased transfer programs in 1999 that were conditional on sending children to school (Bolsa Escola) and stopping child labor (PETI). In the period from 2003 to 2016, they were combined into a single program called Bolsa Família (Family Grant). It achieved widespread coverage.

According to Góes and Karpowicz (2017, p. 4), 'the decline in overall inequality in Brazil was driven by both falling inequality within states and income convergence across states." They argue that "most of the change in Gini can be explained by income growth, higher schooling levels and labor formalization, but the targeted social program, Bolsa Família, also contributed to income convergence" (Góes and Karpowicz, 2017, p. 4). Indeed, in the period from 2004 to 2014, there was a change in the Gini index in Brazil, as can be seen in figure 1. It fell f from 0.54 in 2004 to 0.49 in 2014 , and other commonly used inequality measures also show declining trends.

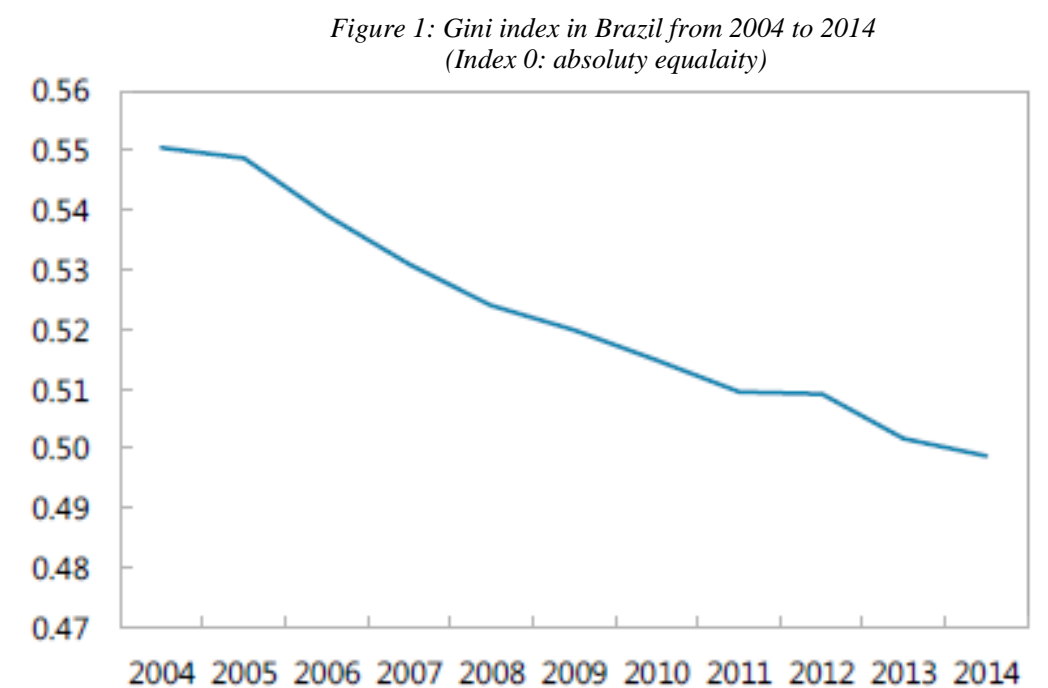

Source: IBGE (2014)

As Góes and Karkowichz (2017) have stated, in decade from 2010 to 2014, Brazil was a poster child for social mobility, since according to the World Bank's international poverty line, it slashed poverty from 25 percent of the population in 2004 to 8.5 percent in 2014, and extreme poverty declined from 12 to 4 percent over the same period. As said by them, "inequality reduction was achieved thanks to a decade-long period of economic growth and deliberate income and social inclusion policies, such as minimum wage increases and targeted social programs" (ibidem, p. 3).

On the other hand, at the end of the first term of former President Dilma Rousseff, the Ministry of Social Development emphasized that Brazil had made a revolution in reducing inequalities in the period from 2004 to 2014 (Ministry of Social Development, 2015). It highlighted education as the fundamental channel of social mobility and presented it as the guiding principle of its actions: "we are convinced that education ensures the definitive overcoming of poverty, as it opens a path of opportunities for everyone" (ibidem, p. 158).

Indeed, the educational agenda occupied a central place in the administrations of the Workers' Party. Both Lula da Silva and Dilma Rousseff focused on education as a national priority. Spending on education reached 5.2\% of GDP, as well as spending on public education grasped almost $16 \%$ of the total government budget. This is as much or more than most OECD countries.

The educational policy of the Lula and Dilma governments seems to have made significant changes in the Brazilian educational system. For instance: it extended the offer of basic education; it expanded the access to higher education; it promoted the expansion of the federal technology education network to include the student in the job market more quickly; it established assessment systems using an internationally benchmarked index that characterizes the progress of each school.

During Dilma Rousseff's first term, the National Program for Access to Technical Education and Employment (PRONATEC) was probably the main initiative developed in order to expand the access to professional qualification and technical courses. It was created in 2011 and had the following aims: i) to stimulate and support the expansion of the physical network that serving technological and professional education; (ii) to extend and diversify the offer of free technological and professional education; and (iii) to integrate programs, projects and actions of technological and professional training.

The expansion of access to higher education was probably one of the most remarkable actions of the Lula and Dilma administrations. It occurred through both the creation of new public universities and in partnership with the private sector. These partnerships were institutionalized by the University for All Program (PROUNI), which promoted the exchange of scholarships at private colleges and universities for exemption of federal taxes. 
As can be seen in the figure 2, the PRONATEC had a great number of enrollments.

Figure 2: Number of enrollments in the PRONATEC (accumulated)

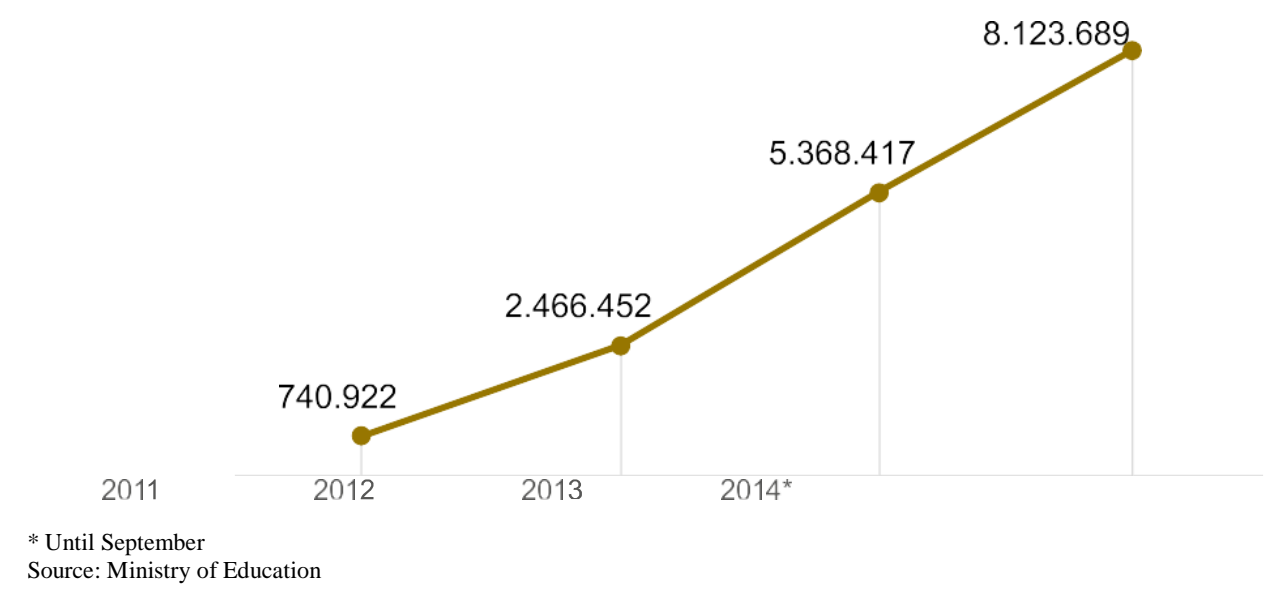

The scholarships provided by PROUNI were of two types, depending on the student's income. They could be full (awarded to students whose family monthly earnings per capita amount to at most 1.5 times the minimum wage) and partial (50\% of the monthly fees, awarded to students whose monthly earnings per capita amount to at most three times the minimum wage). On average, each year, PROUNI provided access to higher education for 120,000 new students (Araújo, 2012).

On June 2, 2011, it was launched the Brazil without Extreme Poverty Plan. It had a clear and ambitious goal: overcoming extreme poverty within one presidential administration period. This commitment was legitimized by the result of the 2010 elections, and confirmed by the elected President Dilma Rousseff during her inaugural speech: "The most stubborn struggle of my administration will be that of the eradication of extreme poverty and the creation of opportunities for everyone" (Ministry of Social Development, 2015, p. 373). But there was indifference among those who saw poverty as part of the natural landscape of Brazil. Their assumption was that it should be understood as a typical phenomenon of a developing country.

According to data from 2014 (ibidem), the Brazil without Extreme Poverty Plan allowed 1.35 million families in extreme poverty to be located, registered and immediately included in the Bolsa Família Program (Family Grant). Another 1.2 million families were located, registered and included in the Program throughout the implementation of the Plan; totaling 2.5 million families. The Program's coverage increased, and it reached 14 million families.

The path of rural productive inclusion allowed for 349 thousand farming families to be assisted. In October $2014,131.3$ thousand of those families had already received at least one installment of the cash transfers. The combination of technical assistance, Productive Asset Oriented Cash Transfers and access to water was essential to facilitate the passage through an extended period of drought and allowed for the recovery of productive activities in the semi-arid region.

The Brazil without Extreme Poverty Plan was structured to face extreme poverty in its different dimensions. It was designed based on a threefold strategy: access to income, opportunities to improve economic inclusion and access to services. Therefore, it was developed in connection with other areas. According to this perspective, and always taking as reference the year 2014, the Plan made viable the professional qualification of 1.5 million low-income workers and created the Bolsa Verde (Green Grant) that benefited 69.8 thousand families of extractivist communities, land reform settlers and riverside communities (Ministry of Social Development, 2015).

In 2015, the Minister of Social Development Tereza Campello made a general assessment of the Brazil without Extreme Poverty Plan, and in line to her words (Campello, 2015), before the launching of Plan, the belief of some sectors was that after a long period of the reduction in the poverty and extreme poverty rates in the country, which began in 2003 in the first Lula da Silva government, the trend starting in 2011 would be a decrease in the rate of reduction, or even a stabilization of the rates. She emphasized that such process was expected due to the growing difficulty to serve the needs of the poorest populations still excluded, which was intensified by the perspective of reduction in the economic growth rate because of the international financial crisis.

However, the Minister highlighted the success of the Plan and stressesed that the said prediction was not confirmed: "Since the launching of the Plan the downward trend continued. The extreme poverty rate fell from $3.8 \%$ in 2011 to $3.1 \%$ in 2013, after a small fluctuation within the margin of error in the 2012/2013 period. Thus, the level achieved by Brazil in 2013 comes close to reaching the global goal of eradicating extreme poverty established by the World Bank to be achieved by 2030, which is 3\%" (Campello, 2015, p. 381).

In 2014, Dilma Rousseff was re-elected against the PSDB candidate Aécio Neves. But in 2016, under the allegation of accounting manipulations in the budget, it was initiated an impeachment process against Rousseff, which was defined by her party (Workers' Party) as a coup d'état, since all the previous presidents proceeded in the same way as 
Rousseff. Moreover, her personal honesty was not questioned. With the support of politicians like current Brazilian President Jair Bolsonaro and Rousseff's Vice President, she was officially impeached. On August 31, the Vice President Michel Temer took her place. In 2018, most of the political forces that approved the impeachment of Rousseff supported the election of the far right candidate Jair Bolsonaro to President.

Bolsonaro administration has a political agenda that is opposed to the agenda of the governments of the Workers' Party (PT). The trajectory of the Brazilian social democratic political cycle was interrupted. The victory of the Workers' Party in 2002 and in the following elections can be understood as the apogee of this cycle in Brazil.

Data such as those provided by the Ministry of Social Development offer empirical support for the analyzes that indicate the reduction of inequality in Brazil in the period from 2004 to 2014, as the approaches that were underlined previously in this paper. However, both the evidence from the Ministry of Social Development and said analyzes must be scrutinized in order to ascertain the consistency and sustainability of the reduction of Brazilian inequality.

\section{THE REDUCTION OF INEQUALITY IN BRAZIL AND THE FUTURE}

Whatever the impact of the educational programs of the governments of the Workers' Party, a question arises as to the long-run impact of a decrease in educational inequality on the distribution of income in Brazil. Even at the end of the period from 2010 to 2014 , the hopes raised by the huge surge in the average level of education had not been fully realized. The impacts of education effects occur in the long run, and they only take place if education programs are not interrupted.

Furthermore, inequitable funding of different levels of Brazilian education is a problem. Brazil funds its public universities at a much higher per student level than its basic education system. The spending per student on tertiary education is nearly six times higher than on primary education, as compared to about $30 \%$ higher on average in OECD countries. As a consequence of this disparity, Brazil has first class public universities that few public school graduates are eligible to enter.

On the other hand, it is always appropriate to recall the findings of Bourguignon, Ferreira, and Menendez (2007). They applied the microsimulation techniques to a PNAD survey to analyze the contribution of inequalities of educational and income opportunity to the formation of inequality in an urban environment. Their paper concludes that the canceling out of inequality due to social origin variables (race, region of birth, and parental education and occupation) would reduce the Theil index of individual earnings by more than one-fifth. They deem these findings disappointing since they only bring Brazil down to an average level of inequality by Latin American standards and a level way above comparable Asian countries. However, it's argued that such 20 percent share should be considered as a lower bound. They also find that a large part (55 to 75 percent) of the impact of factors of origin on individual earnings is associated with parental schooling. Lastly, 70 percent of this impact can be imputed to the direct effect of factors of origin on earnings while the remaining 30 percent corresponds to the indirect effect of social origins going through education - that is, the equalization of schooling opportunities.

Moreover, according to the way that the Bolsa Escola program was designed, it's estimated that it would reduce poverty incidence by just over one percentage point only, and the Gini coefficient by half a point (Bourguignon, Ferreira, and Menendez, 2007). Both the proportion of children enrolling in school in response to program availability and the degree of reduction of poverty turn out to be rather sensitive to transfer amounts, and rather insensitive to the level of the meanstest. "This suggests that the targeting of the Brazilian Bolsa Escola program is adequate, but that poverty reduction through this instrument, although effective, is not magical" (ibidem, p. 25).

However, the main problem now is another. It's the far right agenda of the Bolsonaro administration. The continuity of the policies to reduce the inequality does not seem to be a priority. Jair Bolsonaro has a long history of making offensive comments about LGBTQ people, indigenous communities, and people of color. His finance minister has said that Brazil is stuck in a social democratic model of uncontrolled, expanding public spending and that government spending will be curbed.

\section{CONCLUSION}

Growth in bottom incomes was particularly strong between 2002 and 2010. By the latter year, the average income of the poorest $50 \%$ of Brazilian adults was some $42 \%$ higher than what it was in 1998. But, as Gethin and Morgan (2018) affirm, though average national income per adult grew at $18 \%$ over such period, the majority of the gains was split between two distant groups: the poorest sectors and the very richest sectors.

So, most individuals in the bottom $50 \%$ saw their incomes grow by nearly twice the national average, but at the same time growth was lowest for middle sectors. The administrations of the Workers' Party seem to have assigned secondary attention to this "squeezed middle class", which is comprised both a lower and upper stratum.

There is enough evidence to affirm that the reduction of inequality in Brazil was marked by a singularity: the elite made significant income gains. The large federal investments and credit subsidies proved lucrative for capital-owners. "The income growth of the rich was facilitated by the absence of any significant reform to the country's regressive tax system, whose income component is mainly borne by the upper-middle class" (Gethin and Morgan, 2018, p. 4). There seems to be no doubt that the bullish economic environment was also took in the growth of finance, and financial products. 
However, elite segments have been the least likely to vote in the Workers' Party, and in 2018 they largely supported the election of Jair Bolsonaro.

Anyway, it is possible to conclude that the reduction of inequality in Brazil was the result of firm political decisions, as well as of the quality in management and implementation of the public policies by the technical teams. It was not a type of development that would naturally take place, one way or another.

Despite the progress in reducing inequality during the governments of the Workers' Party, it is also possible to conclude that historical prejudices against the poor remain alive in Brazil. It's a consequence of the legacy of slave society. Such legacy reproduces the perspective of a dual society, according to following logic: us, those who work and contribute versus them, those who receive social benefits and abuse the system. This means holding the poor accountable for their own situation, and it shows that overcoming poverty can be as difficult as overcoming prejudice.

However, for the future of Brazil, it is crucial the country to keep moving in the direction of the reduction of the inequalities. This is the perspective of economic growth with social inclusion. It is the way to combine three fundamental principles for the progress of the democratic societies, as Keynes (1963) described them. They are economic efficiency, social justice and individual liberty.

\section{REFERENCES}

- Araújo, A. A. de. (2012). "Access to Higher Education in Brazil with Reference to Prouni”, in Higher Education Studies, Toronto, v. 2, n. 1, pp. 32-37.

- Barro, J.; Lee, J.-W. (2010). "A new data set of educational attainment in the world, 1950-2010", in Working Papers Series - National Bureau of Economic Research NBER Working Paper, 15902, Cambridge, MA, https://www.nber.org/papers/w15902 (accessed March 5, 2019).

- Bourguignon, F., F. H. G. Ferreira, and M. Menendez (2007). "Inequality of Opportunity in Brazil", in Review of Income and Wealth 53, no. 4, pp. 585-618.

- Campello, T. (2015). "The end to extreme poverty is just beginning", in Tereza Campello, Tiago Falcão and Ana Patrícia Vieira da Costa (eds.), Brazil without poverty. Brasília: MDS.

- Cogneau, D.; Gignoux, J. (2008). "Earnings inequality and educational mobility in Brazil over two decades", in Stephan Klasen and Felicitas Nowak-Lehmann (eds.), Poverty, inequality, and policy in Latin America. Cambridge, Massachusetts: The MIT Press, pp. 47-84.

- Gethin, M.; Morgan C. (2018). "Brazil divided: hindsights on the growing politicisation of inequality", in World Inequality Lab, 3, https://wid.world/document/divided-brazil-hindsights-on-the-growing-politicization-of-inequalitywid-world-issue-brief-2018-3/ (accessed March 6, 2019).

- Góes, C.; Karpowicz, I (2017). Inequality in Brazil: A regional perspective, in IMF Working Papers,17/225, https://www.researchgate.net/publication/321791159_Inequality_in_Brazil_A Regional_Perspective ( accessed March 4, 2019).

- Goldthorpe, J. H. (2005). "Progress in sociology: The case of social mobility research", in Stefan Svallfors (ed.), Analyzing inequality: Life chances and social mobility in comparative perspective. Stanford: Stanford University Press, 2005, pp. 56-82.

- IBGE (2014). Pesquisa nacional por amostra de domicílios: síntese de indicadores. Rio de Janeiro: IBGE.

- Keynes, J. M. (1963). Essays in persuasion. New York: W.W. Norton \& Company.

- Keller, Y. (2012). Inequality and economic growth in Brazil, University of Zurich, Faculty of Economics, Business Administration and Information Technology, 2012 (Bachelor Thesis).

- Kinloch, G. C. (1987). Social stratification: an annotated bibliography. New York: Garland.

- Medeiros, M. (2016) "Income inequality in Brazil: new evidence from combined tax and survey data", in World Social Science Report, 2016. Paris: UNESCO.

- Ministry of Social Development (2015). Brazil without poverty. Brasília: Ministry of Social Development. Brasília: MDS, 2015.

- Pareto, V. (1968) [1901]. The rise and fall of the elites: An application of theoretical sociology. New Jersey: The Bedminister Press.

- Smith, R. E (2008). "The past, present, and future of income distribution in Brazil, 1960-2007”, in IX Congress of the Brazilian Studies Association (BRASA), New Orleans, Louisiana, March 27-30, 2008, http://www.brasa.org/wordpress/Documents/BRASA_IX/Russell-Smith.pdf (accessed March 5, 2019).

- Van de Gaer, D. (1993). Equality of opportunity and investment in human capital, Catholic University of Leuven, Faculty of Economics, Leuven (PhD Thesis).

- Veblen, T. (2007) [1899]. The theory of the leisure class. Oxford: Oxford University Press.

\footnotetext{
${ }^{1}$ It can be chosen, for example, the Gini of average earnings by category of origin. In their general form, these Van of Gaer indices are written $\mathrm{VdG}=\mathrm{I}\{\mathrm{E}(\mathrm{y} l \mathrm{lo})\}$, where $\mathrm{I}$ is an inequality index and $\mathrm{E}(\mathrm{y} l \mathrm{o})$ is the earning expectation conditional on social origin 0 .
} 